\title{
GRAZING MANAGEMENT INFLUENCES ON SEASONALITY AND PERFORMANCE OF RYEGRASS AND REDCLOVERIN A MIXTURE
}

G.P. COSGROVE and R.W. BROUGHAM Grasslands Division, DSIR, Palmerston North

\section{Abstract}

Grazing management influences on the production and species composition of a ryegrass, red and white clover pasture were evaluated over 3 years. Pastures were grazed by cattle frequently in either winter or summer and infrequently for the remainder of the year or grazed infrequently all year. Frequency was determined by the height of herbage pre-grazing and was $10.12 \mathrm{~cm}$ for frequent grazing and $15.20 \mathrm{~cm}$ for infrequent grazing.

Annual herbage production of $15.1+\mathrm{DM} / \mathrm{ha}$ was not influenced by grazing management but seasonal production was. Management caused both instantaneous and longer term effects on production of component species. Lower summer production because of frequent grazing in that season sejuitied from a reduction in red ciover production from 2.75 to $1.3 \mathrm{t} \mathrm{DM} / \mathrm{ha}$. However, ryegrass production in spring was increased by $60 \%$ and in summer it was more than doubled by this grazing treatment.

Frequent grazing in winter also increased ryegrass and reduced red clover production in summer compared with infrequent grazing all year but had no effect on ryegrass production in spring.

Red clover plant density was unaffected by the different grazing managements imposed for two and a half years but subsequently was lower under frequent summer grazing.

Red clover dominance in summer and its effect on ryegrass production in spring can be controlled by more frequent grazing in summer and a more even species balance results. Emphasis on spring or summer production can be achieved through grazing management without affecting total production.

Keywords: Red clover, ryegrass, grazing frequency, cattle grazing, herbage production, seasonal production.

\section{INTRODUCTION}

Studies in Manawatu lowland have demonstrated the ability of 'Grasslands Pawera' red clover (Trifolium pratense) to produce high herbage yields in summer and complement grasses in seasonal production (Pineiro \& Harris, 1978; Harris \& Hoglund 1980). Higher animal liveweight gains have resulted from the superior summer-autumn growth of red clover based pastures compared with perennial ryegrass (Lolium perenne) - white clover (Trifolium repens) dominant pastures (Brougham, 1981).

However, ryegrass and red clover are not perfectly complementary in seasonal pasture (Harris et al.1980) or animal (Brougham, unpub. data) production because of competitive influences. Aggressive red clover growth in summer can deplete ryegrass density and reduce production in winter and early spring causing a more summer dominant spread of production, with feed shortages during spring. The greater persistence and competiveness of Pawera compared with older red clover cultivars (McDonald, 1971) means the severity and duration of aggressive effects on associated grasses are probably greater. 
Grazing management effects on different species in mixed pastures and interactions with seasons are not well understood. Where pastures are composed of species with different seasonal growth periods scope exists to manipulate changes in species dominance through grazing management (Jones, 1933). Changes in grazing frequency and intensity influence seasonal and total productivity through effects on individual pasture species (Brougham, 1960). Nui ryegrass and Pawera red clover yields are more responsive to changes in defoliation frequency than other ryegrass and red clover cultivars which should offer greater scope to influence species yields and balances through grazing management (Lancashire, 1977; Pineiro \& Harris, 1978a). However, in a comparison of frequent with infrequent grazing all year, ryegrass - red clover balance was unaffected and frequent grazing lowered total yield (Pineiro \& Harris, 1978a).

The objective of this study was to examine the effect of imposing seasonal changes in grazing frequency on production of a ryegrass - red clover pasture grazed by cattle, and to investigate the potential to promote a more even seasonal spread of production by reducing red clover dominance.

\section{MATERIALS AND METHODS}

The experiment was conducted at the Aorangi research area of Grasslands Division, DSIR, near Palmerston North, on a Kairanga sandy loam soil. A pasture mixture of 'Grasslands Nui' perennial ryegrass (15 kg/ha), 'Grasslands 4708' tetraploid hybrid ryegrass (15 kg/ha), 'Grasslands Pawera' red clover $(6 \mathrm{~kg} / \mathrm{ha})$ and 'Grasslands Pitau' white clover ( $3 \mathrm{~kg} / \mathrm{ha}$ ) was sown in October 1979 and allowed a 9 month pretrial establishment phase with periodic grazing by sheep. Experimental grazing treatments and pasture measurements commenced in late winter 1980.

Three different cattle grazing managements were compared in randomised block layout with 3 replicates. [Plot size was 0.04 ha $(20 \times 20 \mathrm{~m})$ ].

1. Grazed whenever herbage height reached $15.20 \mathrm{~cm}(\mathrm{I})$.

2. Grazed whenever herbage height reached $10.12 \mathrm{~cm}$ during winter (April-July inclusive) and as for treatment 1 during the remainder of the year (FW).

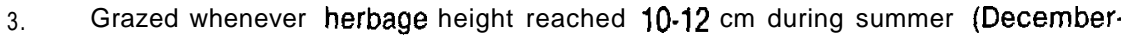
March inclusive) and as for treatment 1 during the remainder of the year (FS).

Mean spelling length for FS in summer was 30 days compared with 48 days for I and FW, and for FW in winter was 49 days compared with 68 for I and FS. Mean spelling length in spring was 47 days for all treatments.

Grazing intensity to $3-5 \mathrm{~cm}$ post grazing herbage height was similar for all treatments. All grazings were completed within 2-3 days using Freisian bulls.

Herbage accumulation was calculated by cutting a strip $(17.5 \mathrm{~m} \times 8.7 \mathrm{~cm})$ to ground level pre- and post-grazing using an electric sheep shearing handpiece. Samples were washed, weighed and subsampled for determination of DM\% and botanical composition. Red clover plant populations were determined by counting plants in 50 randomly thrown quadrats $(100 \mathrm{~cm} \times 10 \mathrm{~cm})$ per plot. Data presented are mean values obtained over 3 measurement years.

\section{RESULTS}

\section{Annual and Seasonal Herbage Accumulation}

Grazing treatments did not affect mean annual herbage production but did influence its seasonal distribution (Fig. la). FS significantly $(P<0.01)$ lowered summer production compared with I. Of total herbage, $36 \%$ was produced in summer under FS grazing compared with $43 \%$ for 1 . A small increase in spring production in FS $(50 \%$ of total Production vs. $45 \%$ in I) partly offset the reduced summer production but this effect did not reach significance. 


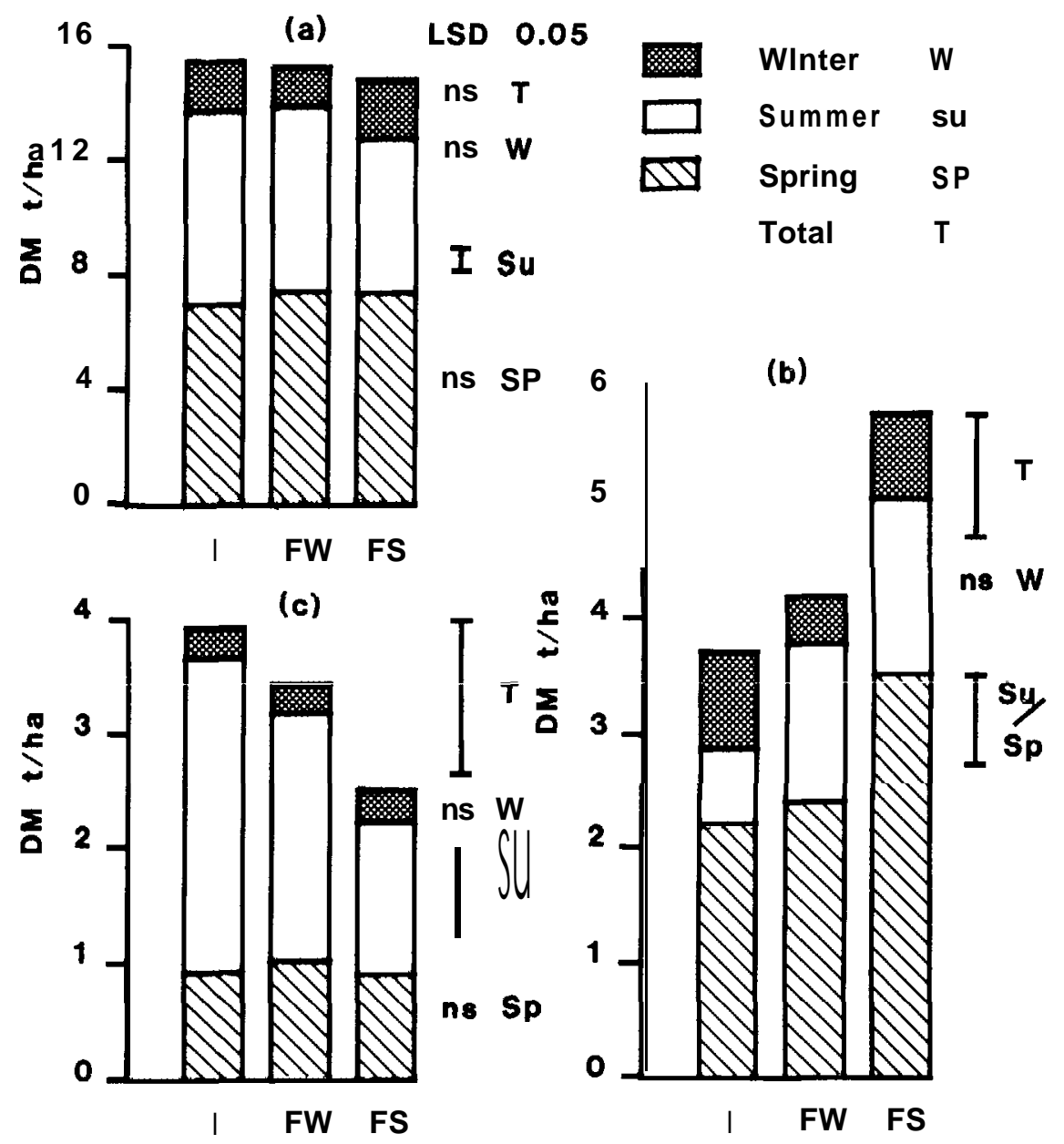

Figure: a) Total annual and seasonal herbage production. b) Ryegrass annual and seasonal production. c) Red clover annual and seasonal production. (Vertical bars indicate least significant differences (LSD) $P<0.05$; ns non significant.)

\section{Ryegrass}

FS grazing resulted in higher annual production of ryegrass $(P<0.01)$ (Fig. 1 b) mainly because of higher production in the spring $(P<0.01)$ and to a lesser extent in the summer $(P<0.05)$. FW grazing resulted in higher ryegrass production in summer compared with I $(P<0.05)$ but there was no significant difference between these treatments in annual production of ryegrass. Lower ryegrass production in winter with FW grazing was not significant.

\section{Red Clover}

The response of red clover production to grazing treatments showed an opposite trend to that of ryegrass with production being lowered by periods of frequent grazing (Fig. Ic). FS severely reduced annual production of red clover $(P<0.05)$ and $F W$ grazing resulted in a similar effect but to a lesser extent (ns). In both treatments only summer production was affected and production during winter and spring was similar to $\mathrm{I}$. 


\section{Other Components}

White clover and unsown grasses were the main contribution to this category of production. Annual and seasonal production of white clover was not influenced by grazing treatment and averaged $3.75 \mathrm{t} \mathrm{DM} / \mathrm{ha} / \mathrm{yr}$ for all treatments. FS significantly $(P<0.05)$ reduced the annual production of unsown grasses $(2.57 \mathrm{t} \mathrm{DM} / \mathrm{ha})$ especially during spring and summer, compared with I (3.75 t DM/ha).

\section{Red Clover Plant Density}

Red clover plant density declined in all treatments during the trial (Table 1). Treatment effects on density did not occur until the end of the third summer by which time FS had a significantly $(P<0.05)$ lower population density than FW or $\mathrm{I}$.

Table 1: RED CLOVER PLANT DENSITY (plants/m²)

\begin{tabular}{|c|c|c|c|}
\hline Management & Summer 1981 & Summer & Summer 1983 \\
\hline Infrequent & 16.5 & 12.4 & 7.9 \\
\hline Frequent winter & 23.2 & 12.5 & 8.5 \\
\hline Frequent summer & 17.7 & 10.6 & 5.0 \\
\hline LSD $(P<0.05)$ & ns & ns & 2.7 \\
\hline
\end{tabular}

ns not significant

\section{DISCUSSION}

Annual pasture production was unaffected by grazing treatments involving seasonal periods of frequent grazing compared with infrequent grazings all year. Many investigations have shown that frequent defoliation will result in lower pasture production (Alcock, 1964). Because of their erect growth habit, Nui ryegrass and Pawera red clover are less productive if grazed too frequently (Corkill, 1981) and this effect of frequent grazing on production has been demonstrated in pastures composed of these species (Harris et al. 1980; Cosgrove \& Brougham, unpubl. data). Also, these authors showed continued frequent grazing did not alter the species balance and therefore this management is of little practical value to control red clover dominance.

However, frequent grazing for only periods of the years while not affecting total annual production, can, by differential effects on component species affect their seasonal and annual production. Frequent summer grazing was severe on red clover production similar to effects recorded by Brougham (1960) and Harris ef al. (1980) for grazing frequently all year. Red clover production was not affected by frequent grazing during winter in contrast to Brougham (1960) who found highest annual yields of red clover resulted from frequent hard grazing during this period. The higher proportion of red clover and lower proportion of ryegrass in all treatments in this experiment probably means red clover did not suffer from, nor respond to the removal of, ryegrass shading during winter.

Improved ryegrass production due to frequent summer grazing was a concommitant effect of the reduced red clover production. Ryegrass is vulnerable to shading from the faster growing red clover in summer. Competition for light can reduce tiller production and increase tiller death (Davies, 1977; Ong \& Marshall, 1979). Reducing the shading effects on ryegrass by frequent grazing resulted in higher ryegrass tiller populations in late summer (Pineiro \& Harris, 1978b).

The response of species to grazing treatment in summer affected both the current and subsequent production of the sward. An associated effect of frequent summer grazing was a large increase in spring ryegrass yield which offered a more even spread of production compared to the high red clover but low ryegrass 
production achieved by grazing infrequently all year. Frequent grazing in winter also increased ryegrass production in summer and although the effects of this treatment on winter and spring production were small in this experiment, larger effects have been recorded (Harris et al. 1980; Parmenter \& Boswell, 1983).

Ingress of unsown grasses was greater with infrequent grazing all year which may have compensated for lower ryegrass production in spring in this treatment compared with FS and FW and resulted in no significant difference between treatments in total spring production. Despite this compensation by unsown grasses the early spring period is especially important because of the earlier commencement of growth in ryegrasses compared with unsown grasses. Maintaining ryegrass content in pastures may be important in restricting the ingress of unsown grasses as occurs in grazing treatments allowing red clover dominance. Furthermore maintenance of ryegrass may also restrict unsown grasses substituting for red clover as plant density declines with age of pasture.

Although Pawera is the most persistent red clover cultivar available, effects of grazing treatment on its persistence remain an important consideration. The tolerance exhibited by red clover plants to different grazing treatments for 2 years, especially frequent grazing during summer, allows some flexibility in the management of red clover based pastures to control excessive red clover dominance. Ryegrass persistency and yield are promoted by frequent summer grazing, although continued application of this management is likely to lead to reduced red clover plant density eventually.

Red clover is of higher digestibility than ryegrass especially in summer (Ulyatt, 1977). Although FS grazing treatment reduced production of the higher quality sward component in summer, improved grass production in spring is also of high quality. The importance of higher herbage production and quality in summer or higher ryegrass production in spring will depend on the farming system.

\section{CONCLUSIONS}

Grazing frequency, particularly in summer, is an important management variable for manipulating ryegrass and red clover balance in grazed pasture. Although summer production is slightly reduced by frequent grazing in summer, a large increase in spring ryegrass production offsets the reduced production from red clover. Frequent grazing in winter is less effective in achieving a more equitable ryegrass red clover distribution.

Achieving a better ryegrass and red clover balance and a more even spread of production without affecting the total yield or persistence of these high producing cultivars is important to ensure maximum benefit in pasture and animal production is obtained from their use. The results demonstrate that a pasture mixture with good summer growth characteristics can be managed to more closely match the requirement of animal production systems especially those involving lactating animals.

\section{ACKNOWLEDGEMENTS}

J.S. Cudby, G.P. Owens and R.G.C. Maxwell for technical assistance. Y.S. Gray and Herbage Laboratory staff for botanical dissections, and staff of the Aorangi Research Farm, Grasslands Division, DSIR, Palmerston North. J.R. Sedcole for statistical analysis.

\section{REFERENCES}

Alcock, M.B. 1964. In "Grazing in Terrestrial and Marine Environments". Ed. D.J. Crisp, pp. 25-41. Blackwell Science Pub., Oxford. Brougham, R.W. 1960. N.Z. J. agric. Res. 3: 125-136. 
1961: Proc. N.Z. Grassld Ass. 42: 54-69.

Corkill, L.; Williams, W.M.; Lancashire, J.A. 1961. Ibid 42: 100-122.

Davies, A. 1977. Proc. int. Mtg. on Anim. Prod. from Temp. Grass/d., Dublin. 36-44.

Harris, W.; Hoglund, J.H. 1960. Proc. XIII Int. Grass/d. Cong.; Leipzig. 239-243.

; Pineiro, J.; Henderson, J.D. 1960. N.Z. J. agric. Res. 23: 339-346.

Jones, M.G. 1933. Emp. J. Exp. agric. 1: 122-129.

Lancashire, J.A. 1977. Dairy farming Ann. 29: 40-50.

McDonald, I.R. 1971. Ann. Rep. Res. Div. N.Z. Depart. of Agric: 204.

Ong, C.K.; Marshall, C. 1979. Ann. Bot. 43: 147-155.

Parmenter, G.A.; Boswell, C.C. 1963. N.Z. J. exp. Agric. 11: 261-267.

Pineiro, J.; Harris, W. 1976a. N.Z. J. agric. Res. 27: 63-92.

1976b. Ibid 27: 665-73.

Ulyatt, M.J.; Lancashire, J.A.; Jones, W.T. 1977. Proc. N.Z. Grass/d Ass. 38: 107-118. 